( С. Б. Фіялка, К.н.с.к., доцент, КПІ ім. Ігоря Сікорського, Київ, Україна

\title{
МЕДІАГРАМОТНІСТЬ УКРАЇНЦІВ З ПИТАНЬ ВАКЦИНАЦІЇ
}

Досліджено наслідки впливу мас-медіа на формування громадської думки щодо вакцинації. Проведено анкетне опитування батьків щодо їх ставлення до вакцинації на сторінці групи «Батьки SOS" у Фейсбуці (67000 учасників). Запитання дали змогу виявити ставлення українців до вакцинації та джерела, якими вони послуговуються, ухвалюючи рішення про щеплення. Обґрунтовано необхідність та запропоновано напрями інформаційнороз'яснювальної роботи серед населення, просвітницьких заходів.

Ключові слова: мас-медіа; комунікація; вакцинація; антивакцинальний рух; «медицина думок»; критичне мислення.

\section{Постановка проблеми}

В Україні в останні роки активно поширюється антивакцинальний рух, учасники якого заперечують доцільність, ефективність та безпеку щеплень. Нерідко представники цього руху керуються релігійними мотивами, або ж стоять на позиціях альтернативної медицини - гомеопатії, остеопатії, хіропрактики, біоенергетики. Серед батьків набирають популярності портали, форуми та повідомлення в соціальних мережах, які поширюють інформацію про те, що вакцинувати дітей немає потреби. Маємо справу з проблемою вибіркового критичного мислення, поширення так званої «медицини думок», коли суспільство вірить історіям малознайомих людей, антивакцинальній пропаганді в цілому, однак не довіряє державі та представникам системи охорони здоров'я й доказовій медицині. Риторика сумніву поширюється мас-медіа й формує громадську думку щодо вакцинації. Не на користь останньої.

Українські медіа транслюють десятки випадків смерті або ж тяжких ускладнень після щеплень. Наприклад, коли після вакцинації у 2008 р. в Краматорську помер старшокласник, численні експертизи виявили, що причина смерті була в іншому. На прес-конференції «Смерть підлітка у Краматорську: професійний медичний діагноз ставлять лікарі, а не політики» про це заявили провідні українські медики: інфекціоністи, імунологи, токсикологи та гематологи [1]. Однак представники мас-медіа посприяли антивакцинальній

(c) 2018 p. 
кампанії, спровокувавши масову відмову від вакцинації серед українців. Зокрема, Телеканал «|нтер» показав документальний фільм власного виробництва «Вакцини. Бізнес на страху», який нібито розкривав «страшну правду про діяльність глобальних медичних корпорацій» «глобальний бізнес, побудований на замовчуванні, круговій поруці фармкорпорацій, В003, урядів країн, тотальній корупції, врешті-решт - на страху» [2]. Окрім того, у мережі з'явилися численні панічні публікації проти щеплень, наприклад: «Частина тернопільських батьків - категорично «проти» щеплень» (https://te.20minut.ua/Zdorovya/ chastina-ternopilskih-batkiv-kategorichno-proti-scheplen 10269518.html), «Діти у Луцьку страждають від болю після вакцинації» (http://podrobnosti.ua/ 2143066-dti-u-lutsku-strazhdajut-vd-bolju-pslja-vaktsinats. html), «Позапланова вакцинація - планова стерилізація» (https://www.ar25.org/node/147 63), «Масові вакцинації провокують епідемії» (https://www. ar25.org/node/14704), «Вітаю, мамо! Я вже труп. Помер учора від вакцинації» (https://www. ar25.org/node/144323), «Злочинну імунізацію української молоді профінансував американський мільярдер - спонсор скорочення «зайвого населення» (https://www.ar25.org/node/ 14398), «Смертельні щеплення замовляли?» (blogs.pravda.com. ua/authors/ppetrenko/524d6354 dae07/), «Небезпечну вакцину таки будуть колоти дітям?» (http: //life.pravda.com.ua/society/ 2008/05/26/4834/), «У Донецьку після вакцинації померла дівчинка» (https://gazeta.ua/articles/life/_u-donecku-pislyavakcinaciyi-pomerla divchinka/ 355449), «Двоє немовлят померли після щеплення» (https:// gazeta.ua/articles/ukraine-newspaper/_dvoye-nemovlyat-pomerli-pislya-scheplennya/304664). Більшість зазначених повідомлень - страшні історії на одиничних прикладах з яскравим емоційним забарвленням та науково необґрунтованими висновками без посилань на фахову літературу.

Тож медіа не в останню чергу призвели до ситуації, що у 2017-2018 роках в Україні реєструються численні спалахи кору внаслідок низького охоплення населення вакцинацією, а наша держава опинилася серед країн з найгіршими показниками за рівнем вакцинації [3]. Проблема, яка склалася 3 «недовакцинацією» українців, уже становить загрозу національній безпеці. Тож є потреба докладного вивчення громадської думки 3 питання вакцинації та організації масштабної кампанії зі спростування поширених мас-медіа антивакцинальних міфів, фахового інформування населення щодо вакцинації, зокрема й через мас-медіа.

\section{Аналіз попередніх досліджень}

Відмови батьків вакцинувати дітей $є$ об'єктом уваги керівництва держав, науковців та лікарів-практиків. Дослідження свідчать, що до основних аргументів антивакцинальників належать сумніви у безпеці вакцин, ризик побічних ефектів, а також «необ- 
ґрунтованість потреби робити щеплення взагалі» [4]. Відмови вакцинувати дітей ґрунтуються на ідеологічних переконаннях [5], етичних міркуваннях [6], недовірі до влади [7] та лікарів [8]. Ідеться також про соціальні чинники та вплив мас-медіа $[9,10]$.

Заслуговують на увагу твердження науковців про те, що відмова від вакцинації є маргінальним феноменом [11]. Крім того, доведено зв'язок між сумнівами щодо проведення щеплень та рівнем освіти батьків [12]. Дослідження, в якому порівнювалося охоплення дітей вакцинацією, показало, що діти, батьки яких надають перевагу альтернативній медицині, менше охоплені вакцинацією. При цьому найчастіше відмовлялися одинокі матері та сім'ї з низькими доходами [13]. Останнім часом на зміну радикальним тенденціям відмови від вакцинації приходять «сумніви щодо щеплень» $[14,15]$. Цей тренд виражається у зростанні кількості батьків, які свідомо вичікують з вакцинацією, відхиляючись від календаря щеплень, чи остерігаються використовувати вакцини окремих виробників.

Серед українських учених досліджуване питання вивчали Ф. Лапій та О. Оніськова, праці яких присвячено розвінчуванню антивакцинальних міфів [16, 17].

\section{Мета роботи}

3'ясувати громадську думку українців щодо вакцинації та завдяки опитуванню зафіксувати міркування, якими вони послуговуються, приймаючи рішення щодо щеплень.

\section{Результати проведених досліджень}

У січні 2018 р. було проведено анкетне опитування батьків щодо їхнього ставлення до вакцинації на сторінці групи «Батьки SOS» у Фейсбуці (група налічує близько 67000 учасників). Загалом було опитано 450 респондентів. Їм було поставлено запитання, що дали змогу виявити ставлення українців до вакцинації та джерела, якими вони послуговуються, ухвалюючи рішення щодо щеплень. Серед респондентів було виявлено $42 \%$ прихильників вакцинації і 27 \% противників, які не роблять щеплень своїм дітям. При цьому кожен третій противник вакцинації має фіктивні записи у формах 3 інформацією про вакцинацію своїх дітей. Решта $31 \%$ потрапили до категорії тих, хто вагається (рис. 1). Важливо, що $50 \%$ противників вакцинації та 90 \% тих, хто вагається, не роб-

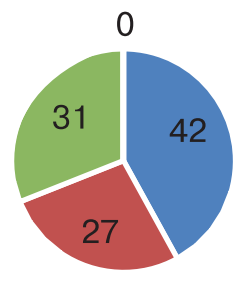

- Прихильники вакцинації

- Противники вакцинації

- Ті, хто вагаються

Рис. 1. Ставлення українців до вакцинації, \% 
лять щеплень не за переконаннями, а під тиском антивакцинальної кампанії.

До джерел інформації щодо вакцинації, яким респонденти довіряють найбільше, належать: соціальні мережі та форуми (32 \%), сайти та література про небезпеку вакцинації (22 \%), друзі та знайомі (20 \%), лікарі при безпосередньому спілкуванні (19 \%), фахова медична література (7\%), пастори в релігійних громадах (2 \%) (рис. 2).

Більшість батьків-противників вакцинації (73 \%) приймають рішення, спираючись на інтернет-джерела, а не завдяки очному візиту до фахівця. При цьому 77 \% батьків, які шукають інформацію в інтернеті, шукають дані про небезпечність вакцин, а не про їх переваги. Основні причини відмови від щеплень такі: не довіряю лікарям; шкода від щеплень перевершує ризики зараження; не бачу потреби; боюся побічних ефектів; не довіряю виробникам вакцин; релігійні переконання; вважаю, що дітей треба прищеплювати не за графіком, а пізніше. Відтак було досліджено риторику прихильників щеплень та антивакцинаторів та надано пропозиції щодо запобігання поширенню серед населення пов'язаних 3 нею міфів. Респонденти мали можливість висловити свої думки щодо вакцинації (173 респонденти надали розгорнуті відповіді, з них 84 особи підтримали вакцинацію, а 89 - не підтримали). Наведемо приклади риторики прихильників і противників вакцинації.

Приклади риторики прихильників вакцинації

Світлана, Київ, учителька, 38 років, мама однієї дитини: Я була дитиною, яку не можна було вакцинувати. Тепер мені 38, і я ненавиджу своїх рідних, які прийняли це рішення. Бо я не можу вільно ходити вулицею.

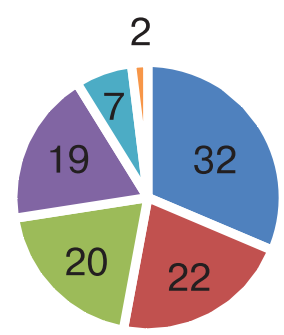

- Сайти та література про небезпеку вакцинації

- Лікарі при безпосередньому спілкуванні

- Пастори в релігійних громадах

- Соціальні мережі та форуми

" Друзі і знайомі

- Фахова медична література

Рис. 2. Джерела, якими послуговуються українці, приймаючи рішення про вакцинацію, \% 
Тарас, Харків, 26 років, підприємець, батько чотирьох дітей: Запис про зроблену вакцинацію не захищає від інфекції, на відміну від проведеної вакцинації.

Наталія, Київ, 43 роки, лікар, мама однієї дитини: Мама завжди оцінює ближчі ризики як більші. Вона ніколи не бачила судом від правцю чи процесу вмирання від дифтерії, інвалідів після корового енцефаліту і поліомієлітних паралітиків, і тому будь-яка неприємність після вакцинації для неї більш значна, ніж імовірний ризик смерті дитини.

Олег, Дніпро, 51 рік, інженер, батько двох дітей: Робив щеплення своїм дітям, бо мені пощастило знайти педіатра, якому можна довіряти. Довіряли, бо на кожне питання діставали вичерпну відповідь.

Ірина, Київ, 42 роки, викладачка, мама двох дітей: Сьогодні проплачувала вакцину КПК для доньки, доброзичлива жіночка шипіла, що я мать-убійца. Відповіла, що спасаю мір, понесу цю гидоту в умовне місце і виміняю на молитвочку проти кору.

Леонід, Тернопіль, 37 років, підприємець, батько трьох дітей: Боятися вакцинації - це про людей, шо не стрижуться, коли вагітні, вірять в те, шо діти родяться глухі і сліпі, і б'ють дитину по губах хвостом живої риби, щоб швидше говорити почала.

\section{Приклади риторики}

антивакцинаторів

Людмила, Київ, 42 роки, перукар, мама двох дітей: Людина, яка перехворіла в дитинстві хоча б трьома дитячими хворо- бами, має значно сильніший захист проти «дорослих хвороб». А повністю щеплені діти, які не перехворіли на жодне інфекційне захворювання, $\epsilon$, по суті, інвалідами.

Святослав, Київ, 38 років, художник, батько чотирьох дітей: Смерть дуже ослабленої дитини від дитячої хвороби дає їй можливість негайно втілитися в здоровому тілі, а не мучитися все життя з вродженими патологіями.

Андрій, Переяслав-Хмельницький, водій, батько двох дітей: Кір, краснуха й дифтерія легкі дитячі хвороби. Вакцинувати нікого не треба.

Вероніка, Київ, 27 років, продавець, мати однієї дитини: Довідки про щеплення дешевші за лікування від них.

Макар, Коростень, 29 років, юрист, батько двох дітей: Це в цивілізаційному збоку хороші вакцини, а в нас індійський Ґанг з підсолоджувачем.

Соломія, Черкаси, страховий агент, мама трьох дітей: Усі кажуть, що вакцинацію придумала влада для зменшення кількості населення.

Дмитро, Кропивницький, 45 років, агроном, батько однієї дитини: Краще б ліки придумали, а не вакцини, особливо від онкозахворювань!

Олена, Черкаси, 44 роки, ресторатор, мама однієї дитини: Я вільна людина, і ніхто не має права змушувати мене робити щеплення. Ще й залякують, що без щеплень у дитсадок і в школу не візьмуть.

Ілона, Хмельницький, 34 роки, лікар: Якість вакцин не хочете обговорити, розумники? А їх 
режим зберігання в аптеках і перевезення без холодильника? А кількість дітей, які перестали ходити й говорити після цього?

Дмитро, Очаків, 35 років, водій, батько двох дітей: Не робимо щеплень собі і своїм дітям, бо діти після щеплень стають тупими або розумово відсталими .

Олексій, Київ, 49 років, історик, батько двох дітей: Думаю, що з сучасними технологіями можна закласти повне вимирання у віці 20 років всіх вакцинованих українців.

Ольга, Біла Церква, 26 років, філолог, мама двох дітей: $B$ українських реаліях креми й шампуні купувати в аптеках небезпечно. Не кажучи вже про ліки, а тим більше вакцини.

Дарина, Вінниця, 28 років, домогосподарка, мама однієї дитини: У мене знайома працює лікарем, своїм дітям щеплень не робить і іншим не радить.

Ганна, Київ, 40 років, вихователька, мама семи дітей: Невже ви думаєте, що Бог створив людину і не дав їй захист від хвороб, і лише в 21 столітті мудрі люди придумали те, що пропустив Творець?

Юрій, Київ, 36 років, економіст, батько однієї дитини: Чому коли питаєш лікаря про ускладнення після щеплення, ніхто з лікарів не бере на себе відповідальність?

Олена, Ужгород, 41 рік, викладачка, мама однієї дитини: Я не довіряю системі в принципі, вважаючи брехливими будь-які iї заяви про бажання чимось мені допомогти, тому коли система починає дуже наполегливо промовляти, що вона хоче якось про мене подбати, то висновок для мене один - мене хочуть надурити. Система щира тільки у батогах, у пряниках же завше брехлива.

Олександр, Одеса, 38 років, менеджер, батько двох дітей: Медицина перетворилася на індустрію, зацікавлену в розширенні ринку споживачів, тобто хронічно хворих. А оскільки коло таких людей обмежене, то винахідливі «бізнесмени» вирішили проблему радикально: вони почали вколювати отруту здоровим людям, перетворюючи їх на хворих.

Сергій, Борщів, 47 років, батько однієї дитини: У вакцинах містяться збудники невиліковних хвороб - раку, СНІДу, туберкульозу, сказу.

Як бачимо, риторика прихильників вакцинації ґрунтується на довірі до лікарів та науково обґрунтованих даних. Натомість риторика антивакцинаторів будується переважно на конспіративних теоріях: на вакцинах заробляють, вакцинація забезпечує вигоду від хвороб, спричинених вакцинами, істину про вакцини приховують від громадськості та релігійних позиціях. Основними аргументами, через які щеплення називають злом, $€$ склад вакцин, їх походження, твердження про те, що щеплення «вбивають імунітет», жахастики про «живу» вакцину та її страшні наслідки. Однак 3 наведених відповідей бачимо також, що не останню роль відіграє недовіра до держави та лікарів. Та й непоодинокі випадки, коли лікарі самі відраджують від щеплень унаслідок звички отримували інформацію з медіа, а не з професійних джерел. 


\section{Висновки}

В Україні назріла потреба перебудови внутрішніх комунікацій та вироблення стратегії реагування на паніки та підвищення довіри до влади. Необхідно видавати брошури, оприлюднювати в мас-медіа офіційну статистику щодо щеплень, проводити фахові роз'яснення щодо того, що робити батькам, які все ж таки вирішили відмовитися від вакцинації. При цьому інформація має бути доступною для розуміння. Медична освіта не $€$ обов'язковою, щоб формувати об'єктивне враження про вакцинацію. Пересічному громадянину достатньо лише орієнтуватись у статистиці, особливостях інфекційних хвороб, імунології та не довіряти бездоказовим твердженням, гомеопатії, БАДам та іншим проявам псевдонауки. Окрім того, варто забезпечити громадський контроль якості вакцин, на рівні держави варто створити адекватну систему моніторингу поствакцинальних ускладнень, забезпечити розвиток юридичного супроводу пацієнтів тощо. Однак, насамперед, має бути соціальна відповідальність тих, хто працює з масовою аудиторією, чиї ідеї завдяки особливим статусу чи технічним можливостям впливають на людей, їх орієнтації. Адже антивакцинальні настрої активно тиражуються, передусім, тому, що для більшості журналістів не так важлива істина, як сенсація.

\section{Список використаної літератури}

1. Смерть подростка из Краматорска не могла быть спровоцирована прививкой от кори и краснухи [Электронный ресурс] // УНИАН. Режим доступа: https://health.unian.net/country/144766-smert-podrostka-iz-kramatorska-ne-mogla-byit-sprovotsirovana-privivkoy-ot-kori-i-krasnuhi.html (дата обращения: 21.01.2018).

2. Вакцини, бізнес на страху [Електронний ресурс]. Режим доступу: https://www.youtube.com/watch?v=92KpSr5xC-w (дата звернення: 21.01.2018).

3. Data, statistics and graphics [Electronic resource]. Retrieved January 11, 2017 from http://www.who.int/immunization/monitoring surveillance/data/en/.

4. European Centre for Disease Prevention and Control. Conducting health communication activities on MMR vaccination. Stockholm: ECDC; 2010. Retrieved December 11, 2017, from http://www.ecdc.europa.eu.

5. Muhsen, K. Risk factors of underutilization of childhood immunizations in ultraorthodox Jewish communities in Israel despite high access to health care services / K. Mushen, R. Abed El-Hai, A. Amit-Aharon at al. // Vaccine. 2012. No. 30(12). pp. 2109-15.

6. Keane, M. Confidence in vaccination: a parent model / M. Keane, M. Walter, B. Patel // Vaccine. 2015. No. 23(19). pp. 2486-93.

7. Omer, S. Vaccine refusal, mandatory immunization, and the risks of vaccine-preventable diseases / S. Omer, D. Salmon, W. Orestein at al. // N Engl J Med. 2009. No. 360(19). pp. 1981-8.

8. Smith, M. Navigating parental vaccine hesitancy / M. Smith, G. Marshall // Pediatr Ann. 2010. No. 39(8). pp. 476-82.

9. Sturm, L. Parental beliefs and decision making about child and adolescent immunization: from polio to sexually transmitted infections / L. Sturm, R. Mays, G. Zimet // J Dev Behav Pediatr. 2005. No. 26(6). pp. 441-52. 
10. Tickner, S. Factors underlying suboptimal childhood immunisation / S. Tickner, P. Leman, A. Woodcock // Vaccine. 2006. No. 24. pp. 7030-6.

11. Sullivan, S. 2009 H1N1 Influenza / S. Sullivan, R. Jacobson, W. Dowdle, G. Poland // Mayo Clinic Proceedings. 2010. No. 85(1). pp. 64-76.

12. Smith, P. Parental Delay or Refusal of Vaccine Doses, Childhood Vaccination Coverage at 24 Months of Age, and the Health Belief Model / P. Smith, S. Humiston, E. Marcuse at al. // Public Health Rep. 2011. No. 126. pp. 135-146.

13. Zuzaka, T. Attitudes towards vaccination users of complementary and alternative medicine versus non-users / T. Zuzaka, I. Zuzak-Siegrista, L. Ristb, G. Staubka // Swiss Med WKLY. 2016. No. 138(47-48). pp. 713-718.

14. Diekema, D. The changing epidemiology of healthcare-associated candidemia over three decades / D. Diekema, S. Arbefeville, L. Boyken at al. // Diagn Microbiol Infect Dis. 2012. No. 73(1). pp. 45-8.

15. Healy, C. How to communicate with vaccine-hesitant parents / C. Healy, K. Pickering // Pediatrics. 2011. No. 127. pp. 127-33.

16. Лапій Ф. Вакцинальні міфи [Електронний ресурс]. Режим доступу: http://zdoroviy.com.ua/content/docs/9.pdf (дата звернення: 21.01.2018).

17. Оніськова О. В. Вакцинація: міфи та факти (огляд літератури) / О. В. Оніськова // Перинатология и педиатрия. 2015. № 3. С. 51-54.

\section{References}

1. (2018). Smert' podrostka iz Kramatorska ne mogla byt' sprovotsirovana privivkoy ot kori i krasnukhi. Retrieved from https://health.unian.net/country/144766-smert-podrostka-iz-kramatorska-ne-mogla-byit-sprovotsirovanaprivivkoy-ot-kori-i-krasnuhi.html [in Russian].

2. (2018). Vaktsyny, biznes na strakhu. Retrieved from https://www. youtube.com/watch?v=92KpSr5xC-w [in Ukrainian].

3. (2017). Data, statistics and graphics. Retrieved from http://www. who.int/immunization/monitoring_surveillance/data/en/ [in English].

4. (2017). European Centre for Disease Prevention and Control. Conducting health communication activities on MMR vaccination. Stockholm: ECDC; 2010. Retrieved from http://www.ecdc.europa.eu [in English].

5. Muhsen, K. \& Abed El-Hai, R. \& Amit-Aharon, A. at al. (2012). Risk factors of underutilization of childhood immunizations in ultraorthodox Jewish communities in Israel despite high access to health care services. Journal of Vaccine, 30(12), 2109-15 [in English].

6. Keane, M. \& Walter, M. \& Patel, B. (2015). Confidence in vaccination: a parent model. Journal of Vaccine, 23(19), 2486-93 [in English].

7. Omer, S. \& Salmon, D. \& Orestein, W. at al. (2009). Vaccine refusal, mandatory immunization, and the risks of vaccine-preventable diseases. Journal of N Engl J Med., 360(19), 1981-8 [in English].

8. Smith, M. \& Marshall, G. (2010). Navigating parental vaccine hesitancy. Journal of Pediatr Ann., 39(8), 476-82 [in English].

9. Sturm, L. \& Mays, R. \& Zimet, G. (2005). Parental beliefs and decision making about child and adolescent immunization: from polio to sexually transmitted infections. Journal of J Dev Behav Pediatr., 26(6), 441-52 [in English].

10. Tickner, S. \& Leman, P. \& Woodcock, A. (2006). Factors underlying suboptimal childhood immunisation. Journal of Vaccine, 24, 7030-6 [in English].

11. Sullivan, S. \& Jacobson, R. \& Dowdle, W. \& Poland, G. (2010). 2009 H1N1 Influenza. Journal of Mayo Clinic Proceedings, 85(1), 64-76 [in English]. 
12. Smith, P. \& Humiston, S. \& Marcuse, E. at al. (2011). Parental Delay or Refusal of Vaccine Doses, Childhood Vaccination Coverage at 24 Months of Age, and the Health Belief Model. Journal of Public Health Rep., 126, 135-146 [in English].

13. Zuzaka, T. \& Zuzak-Siegrista, I. \& Ristb, L. \& Staubka, G. (2016). Attitudes towards vaccination users of complementary and alternative medicine versus non-users. Journal of Swiss Med WKLY, 138(47-48), 713-718 [in English].

14. Diekema, D. \& Arbefeville, S. \& Boyken, L. at al. (2012). The changing epidemiology of healthcare-associated candidemia over three decades. Journal of Diagn Microbiol Infect Dis. , 73(1), 45-8 [in English].

15. Healy, C. \& Pickering, K. (2011). How to communicate with vaccine-hesitant parents. Journal of Pediatrics, 127, 127-33 [in English].

16. Lapii, F. (2018). Vaktsynalni mify. Retrieved from http://zdoroviy.com.ua/ content/docs/9.pdf [in Ukrainian].

17. Oniskova, O. V. (2015). Vaktsynatsiia: mify ta fakty (ohliad literatury). Journal of Perinatologiya i pediatriya, 3, 51-54 [in Ukrainian].

Исследованы последствия влияния масс-медиа на формирование общественного мнения о вакцинации. Проведен анкетный опрос родителей о их отношении к вакцинации на странице группы «Родители SOS" в Фейсбуке (67000 участников). Приведены примеры высказываний сторонников прививок и антивакцинаторов. Обоснована необходимость и предложены направления информационноразъяснительной работы среди населения, просветительских мероприятий.

Ключевые слова: масс-медиа; коммуникация; вакцинация; антивакцинаторство; «медицина мыслей»; критическое мышление.

The effects of mass media on the formation of public opinion on vaccination have been investigated. A questionnaire survey of parents about their attitude to vaccination on the page of the group 'SOS Parents' on Facebook (67,000 participants) was conducted as well. The respondents' feedback made it possible to identify the attitude of Ukrainians towards vaccination and the source they were using when making decision on vaccination.

Keywords: mass media; communication; vaccination; anti-vaccination; 'medicine of thoughts'; critical thinking. 